Contents list available at Multidisciplinary Journal website Multidisciplinary Journal

Journal homepage: https://jurnal.unej.ac.id/index.php/multijournal

\title{
Penerapan Protokol Kesehatan COVID-19 di Era New Normal Pada Kampung Tangguh Desa Karangdoro, Terminal Jajag, dan RTH Maron Genteng, Kabupaten Banyuwangi
}

\author{
The Implementation Of Health Protocol of COVID-19 in New Normal Era in the Karangdoro Resilient \\ Village, Jajag Bus Station, and RTH Maron Genteng, Banyuwangi Regency
}

\author{
Winarso Sugeng ${ }^{1}$, Prastyantoko Kukuh ${ }^{2}$, Prasetya Dhanny ${ }^{3}$, Yuliani Elia ${ }^{4}$, Pratiwi Ogis ${ }^{5}$, Aprilia Rizqi ${ }^{6}$ \\ ${ }^{1}$ Universitas Jember, Jember \\ ${ }^{2}$ Universitas Jember, Banyuwangi \\ ${ }^{3}$ Universitas Jember, Banyuwangi \\ ${ }^{4}$ Universitas Jember, Banyuwangi \\ ${ }^{5}$ Universitas Jember, Banyuwangi \\ ${ }^{6}$ Universitas Jember, Banyuwangi \\ Email: ogismega@gmail.com
}

\begin{abstract}
ABSTRAK. Virus corona atau yang sering di singkat COVID-19 adalah virus yang pada awal tahun 2020 mejadi penyakit yang menyerang masyarakat dan sangat menakutkan bagi seluruh warga di dunia. Banyuwangi merupakan Kabupaten terdampak Covid-19 dengan data sebaran positif sebanyak 1911 jiwa, dinyatakan sembuh 1463 jiwa dan terkomfirmasi meninggal sejumlah 159 jiwa, sehingga dilihat penerapan protokol kesehatan terhadap OVID-19 di Banyuwangi. Sehingga dilakukan penerapan terhadap Covid-19 untuk meminimalisir penularan nya. Penerapan ini dilihat dari beberapa tempat yaitu desa tangguh Karangdoro, Terminal Jajag, dan RTH Maron. Terdapat penanganan di desa tangguh yang dilakukan oleh kepala desa dengan diadakannya desa tangguh sehingga dapat meminimalisir penularan covid-19 dan juga membentuk masyarakat yang berdaya guna baik. Melihat segi sanitasi lingkungan terhadap pembuangan limbah air sisa cuci tangan yang ada di RTH Maron yang tidak di kelola menggunaan IPAL sehingga protocol kesehatan yang ada di RTH Maron masih belum terpenuhi dengan baik. Pada pnerapan di terminal jajag sesuai dengan hasil observasi dihasilan bahwa masyaraat sudah banyak yang tidak memperdulian protokol kesehatan dikarenakan issu di masyarakat yang beredar tentang persebaran covid-19 salah. Solusi dan upaya penerapan protokol Kesehatan di era New Normal adalah dengan Mematuhi dan menerapkan Protokol Kesehatan minimal yang harus di patuhi di era New Normal yaitu 3 M (Menggunakan Masker, selalu Menjaga Jarak, dan Mencuci Tangan) dapat meningkatkan pencegahan persebaran virus COVID-19 sekaligus dapat meningkatkan kebersihan tubuh untuk menghindari berbagai virus yang dapat menyerang tubuh. Semua segmen masyarakat harus bisa bergotong royong dalam kedisplinan penerapan protocol Kesehatan.
\end{abstract}

Kata Kunci: Era New Normal, COVID-19, Desa Tangguh Karangdoro, Terminal Jajag, RTH Maron.

\begin{abstract}
Corona Virus or COVID-19 is a virus outbreak in the early 2020 attacking the society and was a terrifying experience for people around the world. Banyuwangi is a regency affected by Covid-19 with the data distribution including 1911 persons positively infected, 1463 persons recovered, and 159 mortality rates. Therefore, it is necessary to study the health protocol implementation in Banyuwangi to minimize the infections. The area of research includes Karangdoro village (resilient village), Jajag Bus station, and RTH Maron. Resilient village is supported by the head of the village to enable health protocol implementation to minimize Covid 19 and to empower its residence against the outbreak. Sanitation is not managed well in RTH Maron since water waste is not IPAL standardized. It indicates that health protocols in not well implemented in RTH Maron. Jajag Bus Station shows low awareness of people on health protocol implementation due to false information on COVID 19. Solution on health protocol in new normal era is obeying and implementing 3 steps including: Masque Wearing, distancing, and hand washing to improve body cleanliness to avoid viruses. Society at all level must be hand in hand to work together by strictly implementing Health Protocol.
\end{abstract}

Key Words: New Normal, Covid19, Resilient Village Karangdoro, Terminal Jajag, RTH Maron. 


\section{Pendahuluan}

Penyakit berkembang secara luas saat ini, dimulai dari penyakit tidak menular dan penyakit menular yang tentunya menyebabkan ancaman bagi derajad kesehatan masyarakat. Dalam hal ini penyakit menular memiliki potensi yang lebih besar untuk penularannya[15]. Virus corona atau yang sering di singkat COVID-19 adalah virus yang pada awal tahun 2020 mejadi penyakit yang menyerang masyarakat dan sangat menakutkan bagi seluruh warga di dunia[17]. virus ini menyebabkan penyakit pada sistem pernafasan mulai dari flu hingga penyakit Middle East Respiratory Syndrome (MERS), dan Severe Acute Respiratory Syindrome (SARS).

Indonesia merupakan negara yang sedang berjuang melawan pandemi Covid 19. Terhitung data sebaran perakhir Oktober 2020 yang dinyatakan positif sebanyak 410.088 jiwa, dinyatakan sembuh sebanyak 337.801 jiwa serta dinyatakan meninggal sebanyak 13.869 jiwa. Dan per tanggal 1 November 2020 terdapat 406.945 kasus COVID19, 13.782 kasus meninggal, dan 338.000 kasus sembuh [1][16]. Langkah pemerintah dalam pencegahan Covid-19 penundaan kegiatan yang melibatkan banyak orang, belajar dan bekerja di rumah, melakukan pengetesan infeksi Covid-19 dan pengobatan secara maksimal.[20] Selain itu, penggunaan alat pelindung diri seperti masker, menjaga kebersihan dengan cuci tangan, pembatasan sosial berskala besar (PSBB) hingga pemberlakuan new normal merupakan kebijakan pemerintah yang telah di implementasikan selama masa pandemi ini.[14] Penerapan new normal ini harus mendapat dukungan gerakan sosial dari level bawah tentang strategi pencegahan penularan karena pandemi ini tidak pasti akan berakhir kapan dan dapat berakibat pada lumpuhnya sosial ekonomi serta tatanan kenegaraan.

Banyuwangi adalah salah satu kabupaten yang ada di Provinsi Jawatimur, dikabupaten Banyuwangi juga memiliki beberapa kasus mengenai Covid-19 [2], bahkan ada suatu wilayah atau desa yang diberlakukan lock down diarenakan banyaknya masyarakat yang tertular oleh virus Covid-19 di Desa Karangdoro[3]. Selain itu juga dinilai penerapan protokol eksehatan covid-19 terutama di era new normal saat ini di beberapa tempat keramaian seperti terminal Jajag dan juga RTH Maron genteng. Dengan begitu dengan diadakan dan dilaksanakannya kunjungan lapangan (Residensi) oleh Universitas Jember tersebut maka penting bagi penulis untuk - Menganalisis Penerapan Protokol Kesehatan di Era New Normal di Kabupaten Banyuwangi.

\section{Bahan dan Metode}

Metode penelitian yang digunakan dalam penelitian ini adalah deskriptif, desain yang digunakan adalah observasional dan wawancara dengan beberapa responden guna menguatkan dan mendukung data yang didapat. Hasil dari observasi dan wawancara dengan responden di analisa dengan membandingkan fakta dilapangan dengan penelitian terdahulu atau beberapa peraturan yang sudah diterbitkan. dalam melakukan pengisian lembar observasi dan kuesioner tim dibagi menjadi 2 dan lalu dilakukan brainstorming antar anggota kelompok untuk mendapatkan hasil yang tepat.

\section{Waktu dan Tempat}

Penelitian ini berlangsung selama 2 hari yaitu pada tanggal 17 oktober dan 18 oktober dan untuk lokasi penelitian ini dilakukan di 3 tempat di Kabupaten Banyuwangi yaitu Kampung Tangguh Karangdoro, Terminal Jajag dan RTH Maron genteng.

\section{Bahan dan alat}

Bahan yang dipakai dalam penelitian ini adalah lembar kuesioner dan lembar observasi. Kuesioner ditujukan untuk mendapatkan hasil dari jawaban responden secara langsung dan lembar observasi ditujukan untuk mengamati lingkungan serta perilaku masyarakat disekitar lokasi penelitian. Sedangkan alat yang digunakan berupa alat tulis standart untuk mengisi kuesioner dan lembar observasi

\section{Prosedur Penelitian}

Penelitian ini diawali dengan kunjungan lapangan langsung ke 3 lokasi tersebut, diawali dari Terminal jajag, RTH Maron dan terakhir Kampung Tangguh Karangdoro. Tehnis dari pelaksanaannya dapat dirangkum sebagai berikut:

1. Tim dibagi menjadi 2 (Bagian lembar observasi dan kuesioner)

2. Setelah dibagi tim berpencar sesuai jobdesknya masingmasing, bagian lembar observasi focus kepada mengamati bagaimana penerapan protocol kesehatan yang ada dan interaksi antar masyarakat satu dengan yang lainnya, sedangkan bagian kuesioner focus untuk mewawacarai pengelola/pekerja/masyarakat untuk mendapatkan data.

3. Data dikumpulkan di cek bersama-sama lalu dilakukan cekking hasil (brainstorming) antar anggota kelompok hingga didapatkan hasil yang valid di tiap lokasinya

4. Setelah data sudah valid dilakukan analisa dan pembahasan

5. Terakhir Penyusunan laporan

\section{Hasil dan Pembahasan}

Kabupaten Banyuwangi merupakan salah satu kota yang terdampak virus Covid 19 sejak Maret 2020. Pada Maret diketahui terdapat 1 orang dalam masa pengawasan dan 1 orang terkonfirmasi positif Covid 19. Berikut merupakan data Covid 19 kabupaten Banyuwangi Bulan MaretNovember 2020 ditampilkan pada tabel 1 yaitu

\begin{tabular}{|c|c|c|c|c|}
\hline NO. & Bulan & ODP & PDP & Konfirm \\
\hline 1 & Maret & 283 & 1 & 1 \\
\hline 2 & April & 737 & 11 & 2 \\
\hline 3 & Mei & 840 & 31 & 4 \\
\hline
\end{tabular}




\begin{tabular}{|c|c|c|c|c|}
4 & Juni & 902 & 53 & 24 \\
\hline 5 & Juli & 946 & 79 & 56 \\
\hline 6 & Agustus & 1282 & 97 & 771 \\
\hline 7 & September & 1523 & 124 & 1293 \\
\hline 8 & Oktober & 1709 & 171 & 1931 \\
\hline 9 & November & 1763 & 187 & 2263 \\
\hline
\end{tabular}

Tabel 1 merupakan data persebaran Covid 19 di Banyuwangi bulan Maret sampai November yang terdiri dari Orang Dalam Pemantauan (ODP), Pasien Dalam Pengawasan (PDP) dan Konfirm atau pasien yang dinyatakan positif Covid 19[3]. Angka pada tabel terus meningkat dari bulan ke bulan secara signifikan. Gambaran signifikansi kenaikan angka penderita Covid 19 dapat disajikan pada gambar 1 yaitu

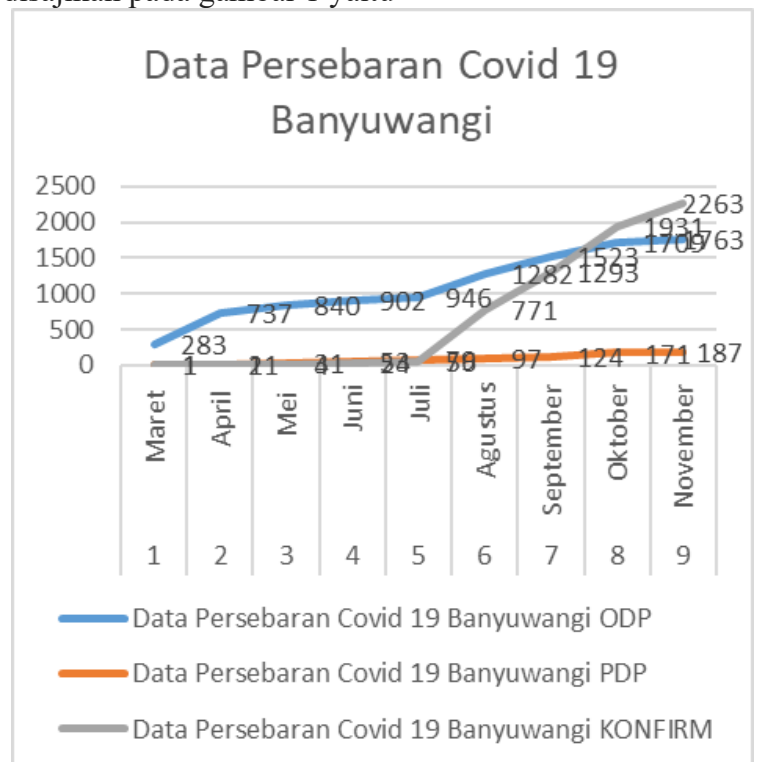

Gambar 1. Diagram Garis Data Persebaran Covid 19 Banyuwangi Maret-November 2020

Gambar 1 dapat dijelakan bahwa ODP dan pasien terkonfirmasi Covid 19 pada bulan Maret sampai November terus mengalami kenaikan dan secara signifikan naik dialami pada bulan Agustus dan terus mengalami kenaikan sampai November. Persebaran PDP mengalami kenaikan tetapi tidak signifikan, kenaikan jumlah terbanyak juga dialami pada bulan Agustus sampai November. Walaupun mengalami kenaikan pasien terkonfirmasi Covid 19, banyak juga pasien yang sembuh dari penyakit ini meskipun ada yang meninggal. Berikut merupakan data pasien yang sembuh dan meninggal buan Maret-November 2020 menurut gambar 2 yaitu

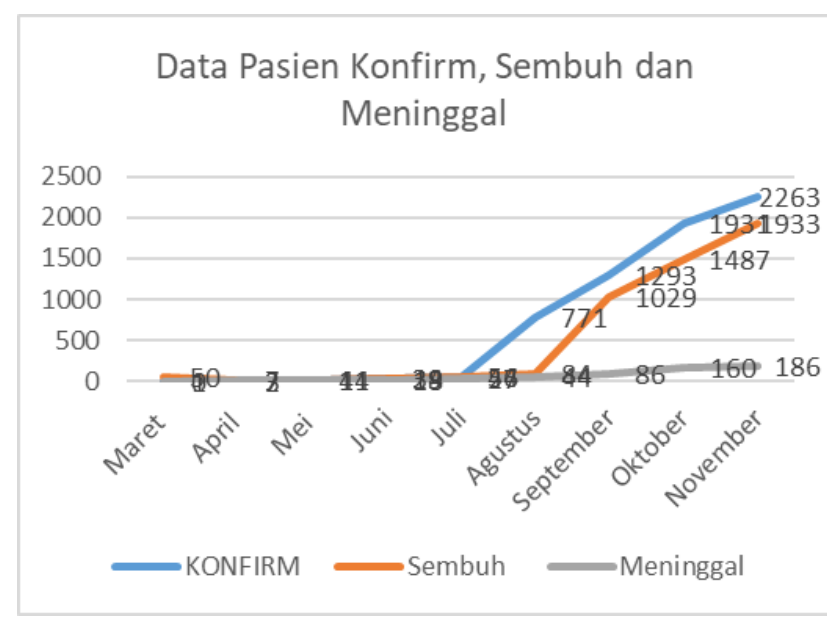

Gambar 2. Diagram Garis jumlah pasien terkonfirmasi Covid 19, Sembuh dan Meninggal bulan Maret-November 2020

Gambar 2 dapat dijelaskan bahwa angka kesembuhan dan pasien terkonfirmasi Covid 19 yang menunjukkan kenaikan secara signifikan. Kenaikan angka pasien terkonfirmasi dibarengi dengan kesembuhan pasien tersebut. Angka kesembuhan lebih tinggi daripada angka kematian merupakan hal yang positif. Menurut Terawan bahwa dalam peningkatan angka kesembuhan dan penurunan angka case fatality rate atau CFR tidak lepas dari beberapa strategi penanganan COVID-19 yang dilakukan yaitu Detect, Prevent, dan Response[5].

Prosentase kejadian Covid 19 berdasarkan jenis kelamin bahwa perempuan lebih banyak terena Covid 19 daripada laki-laki yang dapat dilihat pada gambar 3 yaitu

\section{BERDASARKAN JENIS KELAMIN}

- Laki-laki Perempuan =Tidak diketahui

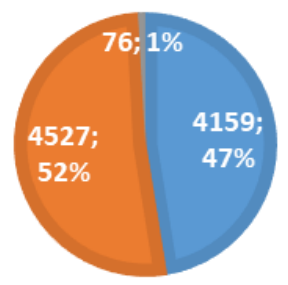

Gambar 3. Perkembangan Covid 19 Berdasarkan Jenis Kelamin

Gambar 3 dijelaskan bahwa persentase perempuan lebih banyak daripada laki-laki yaitu sebesar 52\%. Penelitian yang dilakukan oleh Siagian menerangkan bahwa untuk jenis kelamin pria juga dianggap sebagai kelompok yang berisiko tinggi. Hal ini dikaitkan dengan pria yang merupakan seorang perokok dan penghisap vape sudah mengalami kerentanan di saluran pernafasannya sehingga mudah terpapar Virus Corona[13]. Temuan ini juga terbukti di Italia dimana tingkat kematian pada pria jauh lebih tinggi dibanding pada wanita. 
Sedangkan berdasarkan jenis kelamin dan rentang usia diketahui usia rentang 20-29 dan berjenis kelamin laki-laki lebih banyak terserang Covid 19, seperti gambar 4 berikut

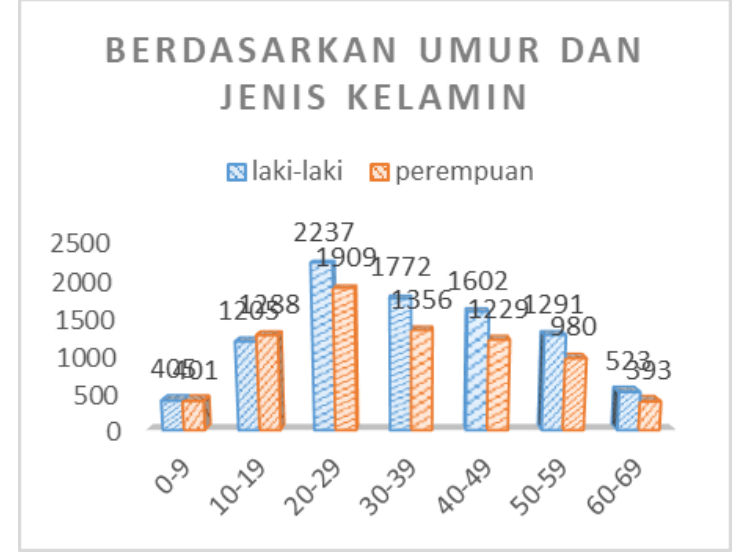

Gambar 4. Berdasarkan Umur dan Jenis Kelamin

Gambar 4 dijelaskan bahwa usia rentang 20-29 dan berjenis kelamin laki-laki lebih banyak terserang Covid 19 dengan nilai sebesar 2237 orang. Sedangkan berdasarkan penelitian Siagian (2020) lansia (usia 45-65 tahun) merupakan kelompok berisiko tinggi terinfeksi Virus Corona akibat sistem kekebalan tubuhnya melemah seiring dengan pertambahan usia.

Menurut Keputusan Menteri Kesehatan RI Nomor HK.01.07/MENKES/382/2020 tentang Protokol Kesehatan bagi masyarakat adalah masyarakat berperan penting dalam memutus rantai penularan Covid-19 agar tidak menjadikan adanya penularan baru/cluster di tempat yang memiliki banyak pergerakan orang, interaksi dan berkumpulnya banyak orang dengan dilakukannya penerapan protokol kesehahatan yang secara umum memuat: [7].

a. Perlindungan kesehatan individu seperti Menggunakan alat pelindung diri berupa masker yang menutupi hidung dan mulut hingga dagu; membersihkan tangan dengan cuci tangan pakai sabun dan air mengalir atau penggunaan antiseptik; menjaga jarak minimal 1 meter; meningkatkan perilaku hidup bersih dan sehat (PHBS).

b. Perlindungan kesehatan masyarakat berupa dengan unsur preventif/pencegahan, unsur penemuan kasus/defect seperti fasilitas deteksi dini Covid 19, dan unsur penanganan secara cepat dan efektif seperti koordinasi dengan dinas kesehatan setempat untuk tracking, pemeriksaan rapid/PCR serta penanganan lain.

Substansi protokol kesehatan pada masyarakat harus memperhatikan titik kritis dalam penularan COVID-19 yang meliputi jenis dan karakteristik kegiatan/aktivitas, besarnya kegiatan, lokasi kegiatan (outdor/indoor), lamanya kegiatan, jumlah orang yang terlibat, kelompok rentan seperti ibu hamil, balita, anak-anak, lansia, dan penderita komorbid, atau penyandang disabilitas yang terlibat dan lain sebagainya.[13] Penerapan protokol kesehatan harus melibatkan peran pihak pihak yang terkait termasuk aparat yang akan melakukan penertiban dan pengawasan. Penerapan protokol kesehatan dilakukan di daerah keramaian bisa dilakukan di ruang terbuka/taman bermain dan Terminal, sedangkan penyelesaian berbasis kebersamaan dilakukan dapat dilakukan dengan pelaksanaan kampung Tangguh[8][9]. Berdasarkan hasil residensi di Ruang Terbuka Hijau Maroon, Terminal Jajag dan Kampung Tangguh Karangdoro yaitu:

1) Pelaksanaan Protokol Kesehatan Kampung Tangguh Karangdoro

Dasar penyelenggaraan kampung tangguh adalah adanya pandemi yang berkepanjangan yang berpotensi rusuh, semakin lama penanganan maka akan menyebabkan kerugian ekonomi dan sosial serta dengan adanya kampung tangguh dapat dilakukan penyelesaian berbasis kebersamaan dan ketertiban (rekayasa sosial)[10][11]. Di desa Karangdoro khususnya area Pondok Pesantren Darussalam bahwa selama pandemi Covid ini telah dilakukan lockdown lokal di area Pondok Pesantren dikarenakan angka kasus covid 19 yang terus naik. Lockdown lokal tersebut didukung dengan adanya organisasi pemuda kampung dan pejabat daerah setempat seperti Kepala desa, RW bahkan sampai petugas luar daerah [20] Pada desa tangguh Karangdoro ini terdiri dari divisi ketangguhan SDM, Kesehatan, Informasi, Keamanan, Logistik, dan Budaya.[4]

Pada divisi ketangguhan SDM ini, disebutkan dengan adanya struktur organisasi yang diketuai oleh Kepala Desa. Struktur organisasi ini dapat dibuat dengan tidak kaku dan dapat disesuaikan dengan keadaan, tetapi dari masingmasing divisi memiliki penanggungjawab masingmasing[12] Pada divisi ketangguhan kesehatan sendiri terdiri dari kader kesehatan yang ada di Kabupaten Banyuwangi dan di luar Kabupaten. Tim kesehatan ini berasal dari Puskesmas atau Rumah Sakit yang ada di Banyuwangi yang ditunjuk dalam memantau dan melayani pengobatan warga secara bergilir. Selain itu, tim kesehatan dan pemuda desa beserta segenap organisasi dalam lingkungan Desa Karangdoro daerah Pondok Pesantren Darusallam mengadakan kegiatan senam bersama bertujuan agar masyarakat dapat bertemu saling sapa dengan masyarakat lain untuk kesehatan mentalnya dengan tetap mematuhi protokol kesehatan. Senam ini dilaksanakan satu minggu sekali pada hari Minggu. Stigma sosial adalah bawa saat warga tertular atau menjadi supect Covid 19 maka sesama warga akan memberi toleransi yang tinggi, semangat dan support optimis untuk sembuh karena mereka sudah sangat memahami informasi Covid 19 sehingga dapat diterapkan dengan baik.[14]

Divisi ketangguhan informasi bertanggungjawab atas keluar masuknya informasi tentang keadaan atau kondisi lingkungan selama masa lockdown. Tim infomasi dibentuk untuk menghindari adanya berita yang tidak benar/hoaks yang dapat menimbulkan kekacauan[10][11]. Bentuk informasi yang disediakan di desa tangguh berupa telepon Call Center secara 24 jam melayani informasi jika diperlukan dan warga yang membutuhkan informasi akan menghubungi secara langsung melalui telepon ke Call Center yang ada.

Divisi ketangguhan keamanan menitikberatkan pada upaya menekan laju penyebaran covid 19 melalui pengendalian 
manusia dengan melakukan screening, riksa barang, pembatasan pergerakan warga pada suatu kawasan, dll. Pihak yang terlibat dalam tim keamanan seperti TNI/Polri, Babinsa, kepala desa dan warga. Pelaksanaan ronda yang berguna untuk memantau kegiatan warga di lingkungan yang kiranya terdapat kerumunan maka petugas akan mengingatkan untuk segera bubar. Selain itu, pemeriksaan kesehatan juga dilakukan di pintu masuk dan keluar, pembatasan keluar dan masuknya warga apabila ada warga dari luar maka petugas keamanan akan memberikan pengertian untuk tidak masuk.

Divisi ketangguhan logistik bertanggungjawab pada pemenuhan kebutuhan dalam desa baik pangan atau lainnya. Pangan sendiri adalah hal yang pokok saat bencana apapun bentuknya agar masyarakat tidak kekurangan pangan apalagi kelaparan. Ketersedian bahan pangan di desa tangguh Karangdoro sangat memadai mulai dari bahan makanan, gas, listrik dan air bersih. Selain itu, juga tersedia SOP pengelolaan lumbung pangan di desa tangguh ini. Sumber ketersediaan stok pangan berasal dari dana pemerintah dan dari masyarakat sekitar yang secara langsung memberikan bantuan kepada desa tangguh baik sayuran atau buah-buahan. Cara pemberian bantuan juga diatur sehingga warga tidak sembarang masuk dalam lingkungan desa yang terkena lockdown, mereka meletakkan di tempat sterilisasi kemudian akan ada petugas yang mengambil barang tersebut.

Divisi ketangguhan budaya dapat dilihat dari sikap gotong royong, kepedulian yang tinggi sehingga muncul rasa kekeluargaan antar warga [14]. Dalam penelitian ini, terdapat 4 budaya yang akan diteliti dari desa tangguh ini yakni

(1) Budaya berbagi Ketika PSBB di daerah pondok pesantren Darusalam yang ada di desa Kedungdoro adalah warga dari luar pondok dengan cepat merespon dalam hal pemenuhan makanan untuk warga yang berada di dalam pondok pesantren yang di lakukan PSBB dengan langsung memberi bantuan makanan seperti sayuran, beras, dan mie instan dan warga menyebutnya lumbung pangan warga. budaya ngaji atau yasinan di desa Karangdoro ditiadakan sementara selama 2 minggu untuk memutus penyebaran COVID-19. Pemberian hiburan berupa video edukasi tentang PHBS (Cuci Tangan, Memakai Masker, dan Jaga Jarak) dari Pemerintah Kab. Banyuwangi bertujuan untuk meningkatkan daya informasi masyarakat dalam menanggapi COVID-19 yang sedang menyebar.[6]

(2) Mengingatkan sesama Toleransi warga dengan warga yang lain terhadap protokol Kesehatan di era New Normal juga dilaksanakan dengan baik seperti saling mengingatkan memakai masker, cuci tangan, dan jaga jarak. Terdapatnya SOP bagaimana cara warga mengingatkan jika diantara mereka tidak disipilin terhadap protocol kesehatan. Bentuk toleransi lain seperti ketika ada masyarakat yang positif COVID-19, warga lainnya akan menyerahkan ke gugus tugas COVID-19 di tingkat RT/RW lalu ke puskesmas untuk di data serta warga tidak merasa khawatir dan takut akan tetapi memberikan semangat kepada warga tersebut [14].
(3) Menolong, Perilaku warga terhadap warga yang positif COVID-19 dengan saling membantu warga yang Positif COVID-19 untuk di serahkan ke posko posko COVID-19 untuk di tindaklanjuti[14]. Budaya menolong dilakukan oleh pemuda-pemuda desa atau karang taruna desa Karangdoro yang menjadi motor penggerak warga dalam bergotong royong untuk membantu warga lainnya yang terkena COVID-19.

(4) Toleransi merupakan sebuah sikap menghargai kepada seseorang yang memiliki suatu perilaku budaya yang berbeda dengan orang lain[14]. Pada warga Karangdoro memegang teguh tepo seliro. Ketika Zona Merah dan new Normal, tepo seliro ini merupakan sikap tenggang rasa yang mampu meningkatkan dalam penurunan angka persebaran COVID-19. Kemudian budaya pengajian warga masyarakat Karangdoro Ketika status Zona Merah di hentikan sementara selama 2 minggu, tetapi Ketika New Normal budaya pengajian tetap dilaksanakan tetapi dengan melakukan protocol Kesehatan.

Dari penjabaran di atas, pelaksanaan desa tangguh Krangdoro dikategorikan menjadi desa yang tangguh dengan total skor 736 dari jumlah responden sebanyak 10 orang. Dikategorikan tangguh bahwa memiliki kemampuan dalam mengelola lumpung pangan sehingga cukup, kemampuan sumber daya lingkungan dalam menangani bencana, adanya sarana komunikasi internal yang dapat dipercaya, adanya tim kesehatan kampung yang membantu warga terdampak, ketaatan warga dalam mematuhi aturan, tradisi lokal yang dapat membantu menghadapi bencana, serta kemampuan psikologis warga dalam menghadapi bencana seperti tidak cemas dan takut berlebihan [12].

2) Pelaksanaan Protokol Kesehatan di RTH Maroon

Observasi di RTH Maron Genteng Banyuwangi dengan menggunakan komponen observasi yang mengacu pada pedoman WHO dan UNICEF mengenai penyediaan layanan penanganan Covid-19 yang didalamnya memuat peraturan tentang higiene sanitasi lingkungan terutamanya pada pengolahan limbah cair. Terdapat 14 komponen yang dibedakan menjadi 2 sub tema komponen meliputi pengelolaan tempat dan observasi lapangan. Pada pengelolaan tempat memiliki 9 komponen. [18][19]

Komponen pertama adalah apakah tersedia tim pengawas dan juga posko covid-19 di RTH Maron genteng, dari hasil observasi dapat di ketahui bahwa di RTH Maron untuk saat ini terutama pada masa new normal ini tidak di sediakan posko penanganan covid-19 sehingga hasil observasi menyatakan bahwa tidak sesuai dengan persyaratan penanganan pencegahan Covid-19 yang seharusnya. Komponen kedua mengenai terdapatnya peraturan untuk menggunakan masker dan menjaga jarak antara orang lain, di RTH Maron sudah terdapat larangan yang di pampang di beberapa tempat mengenai penggunaan masker dan berjaga jarak

Komponen ketiga adalah apakah dilakukan pengecekan suhu atau tidak terhadap seluruh warga atau orang yang masuk atau berkegiatan di kawasan RTH Maron Genteng, 
pada hasil observasi menunjukkan bahwasanya tidak ada pengecekan suhu tubuh, sehingga hal tersebut tidak sesuai dengan syarat yang seharusnya di terapkan sehingga pada komponen tersebut mendapatkan hasil tidak sesuai dengan syarat yang di tentukan untuk penanganan Covid-19.

Komponen keempat adalah melakukan pembersihan dan penyemprotan desinfektan di wilayah RTH Maron, dari hasil observasi yang saya lakukan adalah mendapatkan hasil tiak sesuai, dikarenakan di RTH Maron sudah tidak di berlakukan penyeprotan desinfekts terhadap li gkungan sekitar RTH Maron dan juga pada fasilitas umum yang ada di RTH Maron.

Komponen kelima membahas tentang adanya sarana cuci tangan dengan mengunakan sabun di RTH Maron, sarana cuci tangan sudah terpenuhi sehingga sudah sesuai dengan aturan yang harus di terapkan, sarana cuci tangan yang di sediakan di RTH Maron lebih dari 3 tempat sehingga tidak hanya satu, tempat cuci tangan dilengkapi juga dengan sabun cuci tangan. Sehingga pada hasil observasi memiliki hasil sesuai dengan syarat yang sudah di berlakukan bahwa pencegahan covid-19 yang harus di lakukan di tempat ramai salah satu nya adalah mewajibkan bercuci tangan dan menyediakan tempat dan alat untuk cuci tangan dengan baik dan benar.

Komponen keenam adalah memasang panduan tata cara cuci tangan yang baik dan benar, hasil dari obsservasi menyatakan bahwa di RTH maron terutamanya pada tempat cuci tangan tidak di sediakan panduan carea untuk mencuci tangan yang baik dan benar.

Komponen ketujuh adalah upaya peminimalisir pengunjung yang datang, hal ini berkaitan dengan Physical Distancing yang harus di terapkan dalam pencegahan penularan virus covid-19, hal tersebut dari hasil observasi di lapangan tidak ada upaya peminimalisiran warga atau pngunjung yang datang dikarenakan tidak ada pembatasan seberapa banyak jumlah pengunjung yang harus ada di sana, sehingga pada komponen ini tidak sesuai dengan syarat yang harsu di pebuhi dalam meminimalisir penularan covid-19.

Komponen ke delapan adalah mewajibkan seluruh pengunjung yang ada di RTH Maron memakai masker, dari hasil observasi menyebutkan bahwa hal tersebut tiak sesuai dengan peraturan dikarenakan tidak ada pemeriksaan yang dilakukan oleh petugas yang menangani RTH Maron untuk menegur masyarakat yang tiak menggunakan masker, sehingga pada point tersebut masih tidak sesuai.

Komponen ke sembilan adalah media infomasi tentang covid yan di pasang di RTH Maron, dari hasil observasi menyatakan bahwa sudah sesuai dengan peraturan yang diwajibkan, dikarenakan paada saat obsevasi lapangan saya lakukan, saya menemukan papan informasi tentang covid yang di tempet di beberapa dinding bangunan yang ada di RTH Maron Genteng, sehingga hal tersebut dharap dapat menjadi masukan untuk masyarakat bahwa harus melihat informasi yang benar mengenai covid-19 dan pencegahan covid-19 yang harus di lakukan.

Subtema kedua adalah observasi lapangan yang mana komponen satu adalah mengenai tempat cuci tangan yang di sediakan di RTH Maron Genteng, sudah di sediakan tempat cuci tangan yang d sedakan di RTH Maron berjumlah 5 tempat cuci tangan, sehingga sudah sesuai dengan syarat yang harus di penuhi dalam pencegahan penularan covid-19.

Komponen ke 2 adalah mengenai penyediaan sabun cuci tangan yang di sediakan bersamaan dengan tempat cuci tangan, dari hasil observasi mendapatkan hasil yang sesuai dikarenakan sudah ada dan disediakan sabun cuci tangan.

Komponen ke 3 adalah pembuangan air limbah atau sisa cuci tangan atau air, hasil observasi diketahui bahwa tidak ada sarana pembuangan limbah cair hasil sisa cuci tangan yang ada di RTH Maron, sehingga limbah cuci tangan yang mengadung bahan kimia dari sabun itu jatuh langsung dan mengaliri lingkungan atau tanah sekitar RTH Maron, hal tersebut tidak sesuai dengan peraturan mengenai lingkungan dikarenakan jika hal tersebut terus dilakukan maka akan merusak lingkungan setenpat, dampak pada lingkungan akan merusakn $\mathrm{pH}$ tanah dan juga poertumbuhan tanaman yang ada di sekitar RTH Maron.

Komponen ke 4 menyatakan bahwa apakah ada IPAL (Instalasi Pengolahan Air Limbah) di RTH Maron, dari hasil observasi menyatakan bahwa sesuai dikareankan terdapat filtering pegolahan air yang ada di RTH Maron Genteng. Sehingga hal tersebut sudah sesuai dengan peraturan mengenai lingkungan.

Komponen ke 5 adalah apakah IPAL digunakan, dari hasil observasi menyebutkan bahwa tidak sesuai dikarenakan IPAL yang ada di RTH Maron kini tidak di gunakan, terutama dalam pengelilaan limbar cair hasil sisa cuci tangan pada saat masa pandemi COVID-19 smpai masa new normal covid-19. Sehingga hal tersebut dikatakan tidak sesuai, yang seharusnya bisa dipergunakan untuk meminimalisir pencemaran lingkungan akibat limbah cair, tetapi IPAL di RTH Maron tidak di gunakan sama sekali.

Dari hasil observasi dapat diketahui bahwa keseluruhan komponen jika di simpulkan di RTH Maron masih tidak sesuai dengan persyaratan sanitas lingkungan pada masa pandemi covid-19 pada saat ini. Dikarenkana pada 14 point yang menghasilkan hasil tidak sesuai ada sejumlah 8 point, sedangkan yang sesuai adalah 6 point, sehingga harus di perbaiki dari point yang tidak sesuai tersebut dijadikan menjadi sesuai sehingga sanitas liungkungan dpat terjada dan juga dapat meminimalisir penularan covid-19 dan menjaga lignkungan tetap sehat

3) Pelaksanaan Protokol Kesehatan di Terminal Jajag

Sesuai Keputusan Menkes Nomor HK.01.07/MENKES/382/2020 Tentang "Protocol Kesehatan bagi Masyarakat di Tempat dan fasilitas Umum dalam Rangka Pencegahan dan Pengendalian Corona Virus Disease 2019(Covid-19)", yang di dalam terdapat sektor tempat umum yang menjadi sorotan mulai tempat wisata, hiburan hingga sarana transortasi umum.[7][8] Salah satu transportasi yang menjadi perhatian adalah jalur darat yang menggunakan Bus, karena aktivitasnya yang membawa penumpang dari kota ke kota/terminal satu ke terminal lain dan menjadi salah satu media penyebaran virus Covid-19 dengan mudah karena banyak bertermu dan berinteraksi dengan orang-orang baru di terminal. 
Berdasarkan hasil observasi yang telah dilakukan dengan komponen-komponen yang disusun berdasarkan Keputusan Kementrain Kesehatan, yaitu tentang protocol kesehatan untuk masyarakat di tempat dan fasilitas umum dalam rangka strategi pencegahan dan pengendalian corona virus disease 2019 (Covid-19)[7][8], ternyata masih ditemukan beberapa ketidak sesuaian yang terdapat disana diantaranya:

1) Tidak adanya cek suhu tubuh di saat ada orang masuk terminal pengelola, pekerja maupun calon penumpang dan penumpang yang datang (Menurut pengelola dan beberapa sampling dengan orang-orang di sekitar terminal, hal tersebut pernah dilakukan tetapi ketika sudah memasuki New Normal kebiasaan tersebut ditiadakan)

2) Hanya ada 1 sarana cuci tangan untuk seluruh orang-orang yang ada di dalam terminal

3) Toilet ada 2 bersebalahan dibelakang kantor pengelola yang digunakan secara bersamaan oleh seluruh orang-orang di terminal

4) Kursi penumpang yang ada diruang tunggu sudah tidak ada lagi tanda sebagai penanda bahwa harus melakukan jaga jarak. (Sebelum New Normal masih ada, tetapi saat ini sudah tidak ada)

5) Pembersihan/sterilisasi area terminal hanya dilakukan 1x seminggu

6) Ada pos kesehatan, tetapi tidak ada petugas yang standby disana

7) Banyak orang-orang di terminal yang tidak menggunakan masker dan tidak berjarak satu dengan yang lainnya.

Selain itu, wawancara dilakukan kepada pengelola terminal yang lebih berfokus kepada bagaimana peran pengelola dalam menciptakan lingkungan yang aman di dalam terminal. Berdasarkan hasil wawancara yang telah dilakukan dengan komponen-komponen telah yang dijelaskan, setelah diberlakukannya New Normal oleh pemerintah banyak yang tidak sesuai atau sudah tidak diterapkan kembali seperti:

1) Sudah tidak ada tim/pokja pencegahan Covid-

2) Larangan masuk dalam terminal bagi orangorang yang mengalami gejala batuk, pilek, nyeri tenggorokan dan/atau sesak nafas.

3) Tidak dilakukan pengecekkan suhu bagi orangorang yang masuk terminal maupun baru datang dari perjalanan menggunakan bus

4) Panduan cuci tangan sudah tidak ada

5) Hand sanitizer sudah tidak ditemukan kembali dibeberapa titik

6) Jam operasional tidak ada pembatasan sama sekali atau berjalan seperti sebelum pandemic terjadi

7) Sudah tidak ada lagi pembatasan jarak antar orang-orang di terminal, terasuk kursi-kursi yang pernah ditandai dulu saat ini sudah tidak ada tandanya lagi.

Berdasarkan wawancara dengan pengelola dan temuan yang ada, kurangnya audit dari pusat dan salah tafsir di masyarakat tentang New Normal yang seolah-olah menimbulkan persepsi bahwa virus Covid-19 telah hilang membuat banyak sekali masyarakat yang mengabaikan protocol kesehatan.Sebagai pengelola yang bertanggung jawab di Terminal Jajag terkait segala aktivitas di dalam dan lingungan terminal, pengelola hanya menghimbau untuk tetap mematuhi protokol kesehatan kepada calon penumpang dan orang-orang di dalam area terminal akan tetapi karena mulai ramainya kembali aktivitas di dalam terminal dan ketidaktegasan pengelola dalam memberlakukan protokol kesehatan di dalam terminal membuat banyak temuan di temukan/ketidaksesuaiaan, yang paling Nampak di terminal jajag adalah sudah tidak adalagi batasan kursi untuk duduk di terminal karena rambu/tanda yang hilang dan interaksi masyarakat disekitar terminal dan di dalam terminal banyak yang tidak menggunakan masker.

Wawancara juga dilakukan dengan para calon penumpang dengan hasil dari wawancara dengan 5 orang pengunjung/calon penumpang di terminal secara mayoritas hampir sama seperti:

1) Mayoritas pengunjung/calon penumpang relatif paham dan tidak memutuskan untuk memaksakan keadaan ketika sedang tidak sehat

2) Hanya 2 orang dari 5 orang saja yang menggunakan masker saat di terminal, lainnya tidak karena menganggap Covid-19 telah pergi/sudah hilang karena sudah New Normal

3) Semua pengunjung/calon penumpang tidak melakukan cuci tangan dengan sabun karena hanya ada 1 tempat cuci tangannya dan terkadang airnya tidak mengalir/sabunnya tidak ada

4) Hanya 2 orang menggunakan yang masker saja tidak suka menyentuh area wajah ketika di tempat umum

5) Semua pengunjung/calon penumpang paham dengan pentingnya menjaga jarak minimal 1 meter, tetapi karena padatnya penumpang dan tidak dipisahkannya kursi ruang tunggu saat masuk era New Normal ini membuat berjarak terkadang sulit untuk dilakukakan.

6) Semua pengunjung/calon penumpang langsung mandi dan mengganti pakaiannya ketika sampai dirumah

7) Semua pengunjung/calon penumpang hanya membersihkan handphonenya jika kotor dan menggunakan kain/tisu

Faktor lain selain dari calon penumpang sendiri adalah tidak lengkapnya sarana prasarana yang ada di terminal pasca penerapan New Normal membuat calon penumpang mau tidak mau untuk mengabaikan beberapa protocol kesehatan seperti: tempat cuci tangan yang hanya 1, toilet yang hanya 1, sudah tidak ada lagi tanda-tanda untuk berjarak antar orang di terminal. Walaupun sudah ada himbauan berupa rambu-rambu besar berupa banner dan poster yang ditempel kurangnya pengawasan dan teguran langsung dari pekerja/petugas/pengelola membuat calon penumpang benar-benar mengabaikan rambu-rambu yang ada.

\section{Kesimpulan}

Protokol Kesehatan Menurut Keputusan Menteri Kesehatan Republik Indonesia Nomot HK.01.07/MENKES/382/2020 tentang Protokol Kesehatan 
bagi Masyarakat harus memuat : Perlindungan Kesehatan Individu dan Perlindungan Kesehatan Masyarakat Substansi protokol kesehatan terhadap masyarakat pada titik kritis harus diperhatikan dalam penyebaran Covid 19 yaitu pada etnis dan karakteristik/ciri kegiatan, besar dan lokasi kegiatan, lama dan jumlah orang yang terlibat dalam kegiatan, kelompok rentan seperti ibu hamil, balita, anakanak, lansia dan penderita penyakit bawaan/komorbid serta disabilitas, dan sebagainya.

Identifikasi Temuan Penerapan Desa Tangguh Covid 19 di Desa Karangdoro Kec Tegalsari, Kab. Banyuwangi adalah Di desa Karangdoro khususnya area Pondok Pesantren Darussalam bahwa selama pandemi Covid ini telah dilakukan lockdown lokal di area Pondok Pesantren dikarenakan angka kasus covid 19 yang terus naik. Pada desa tangguh Karangdoro ini terdiri dari divisi ketangguhan SDM, Kesehatan, Informasi, Keamanan, Logistik, dan Budaya. SDM ini, disebutkan dengan adanya struktur organisasi yang diketuai oleh Kepala Desa. Sedangkan Divisi Kesehatan melibatkan seluruh petugas Kesehatan di Kab. Banyuwangi karena situasi yang darurat dengan melakukan swab test pada semua Pondok Pesantren Darussalam. Divisi ketangguhan informasi bertanggungjawab atas keluar masuknya informasi tentang keadaan atau kondisi lingkungan selama masa lockdown. Tim infomasi dibentuk untuk menghindari adanya berita yang tidak benar/hoaks yang dapat menimbulkan kekacauan. Divisi ketangguhan keamanan menitikberatkan pada upaya menekan laju penyebaran covid 19 melalui pengendalian manusia dengan melakukan screening, riksa barang, pembatasan pergerakan warga pada suatu kawasan, dll. Divisi ketangguhan logistik bertanggungjawab pada pemenuhan kebutuhan dalam desa baik pangan atau lainnya. Divisi ketangguhan budaya dapat dilihat dari sikap gotong royong, kepedulian yang tinggi, sehingga muncul rasa kekeluargaan antar warga. Pada desa tangguh Karangdoro, warga secara langsung mempunyai rasa gotong royong dan kepedulian yang tinggi dengan adanya masyarakat yang memberikan bantuan secara langsung.

Berdasarkan observasi di RTH Maroon , Genteng, Observasi di RTH Maron Genteng Banyuwangi dengan menggunakan komponen observasi yang mengacu pada pedoman WHO dan UNICEF mengenai penyediaan layanan penanganan Covid-19 yang didalamnya memuat peraturan tentang higiene sanitasi lingkungan terutamanya pada pengolahan limbah cair. Pada pengelolaan tempat memiliki 9 komponen. Dari komponen komponen tersebut RTH Maron ada beberapa yang sesuai standart dan ada beberapa yang tidak sesuai standart pedoman WHO. Yang sesuai standart seperti, warga yang berkunjung di RTH Maron sudah mematuhi peraturan memakai masker dan menjaga jarak, sudah di sediakan tempat cuci tangan yang $d$ sedakan di RTH Maron berjumlah 5 tempat cuci tangan, dan yang tidak sesuai standart seperti RTH Maron untuk saat ini terutama pada masa new normal ini tidak di sediakan posko penanganan covid-19, di RTH Maron sudah tidak di berlakukan penyeprotan desinfekts terhadap li gkungan sekitar RTH Maron dan juga pada fasilitas umum yang ada di RTH Maron, di RTH maron terutamanya pada tempat cuci tangan tidak di sediakan panduan carea untuk mencuci tangan yang baik dan benar, tidak ada sarana pembuangan limbah cair hasil sisa cuci tangan yang ada di RTH Maron, Sistem IPAL (Instalasi Pengolahan Air Limbah) di RTH Maron kini tidak di gunakan lagi.

Berdasarkan observasi di Terminal Jajag petugaspetugas/pekerja yang ada di dalam terminal sudah banyak yang acuh dengan tugas seperti protocol kesehatan, kembali lagi karena ada miss persepsi terkait pandangan New Normal membuat pekerjapun juga beranggapan virus Covid-19 sudah hilang dari Kabupaten Banyuwangi. Sorotan utama sebetulnya harus diberikan kepada pada petugas/pekerja di terminal, karena merekalah yang menjalankan fungsi maintenance segala infrastruktur, alat dan sebagai orang-orang yang menjadi contoh bagi orangorang di dalam terminal.

Solusi dan upaya penerapan protocol Kesehatan di era New Normal adalah dengan Mematuhi dan menerapkan Protokol Kesehatan minimal yang harus di patuhi di era New Normal yaitu 3 M (Menggunakan Masker, selalu Menjaga Jarak, dan Mencuci Tangan) dapat meningkatkan pencegahan persebaran virus COVID-19 sekaligus dapat meningkatkan kebersihan tubuh untuk menghindari berbagai virus yang dapat menyerang tubuh. Semua segmen masyarakat harus bisa bergotong royong dalam kedisplinan penerapan protocol Kesehatan.

\section{Referensi}

1. http://sehatnegeriku.kemkes.go.id/baca/rilis media/20201020/2835466/angka-kesembuhan-covid-19-indonesiarata-rata-dunia/. [diakses 4 Desember 2020]

2. http://www.dpmd.jatimprov.go.id// buku saku Desa Tangguh (diakses pada tanggal 30 Oktober 2020)

3. https://corona.banyuwangikab.go.id/ [diakses 25 Oktober 2020]

4. https://covid19.go.id/ Buku Saku Desa Tangguh Covid 19 (diakses pada tanggal 30 Oktober 2020)

5. https://www.kemkes.go.id/ Kesiapsiagaan Menghadapi Infeksi Covid 19 (diakses pada tanggal 30 Oktober 2020)

6. Ilpaj \& Nurwati. 2020. Analisis Pengaruh Tingkat Kematian Akibat Covid-19 Terhadap Kesehatan Mental Masyarakat Di Indonesia. Jurnal Pekerjaan Sosial. Universitas Padjajaran: Bandung.

7. Kementerian Kesehatan Republik Indonesia, Protokol Kesehatan Bagi Masyarakat Di Tempat Dan Fasilitas Umum Dalam Rangka Pencegahan Dan Pengendalian Corona Virus Disease 2019 (Covid19).

(http://perpustakaan.litbang.kemkes.go.id/lokaciamis/index.php?p=sh ow_detail\&id=1867). [diakses 15 Oktober 2020]

8. Kementerian Kesehatan Republik Indonesia, Pedoman Pencegahan dan Pengendalian Coronavirus Disease (Covid-19) (Jakarta: Direktorat Jenderal Pencegahan dan Pengendalian Penyakit, Maret 2020), hlm. 11

9. Kementerian Kesehatan Republik Indonesia, Pedoman Pencegahan dan Pengendalian Coronavirus Disease (Covid-19) (Jakarta: Direktorat Jenderal Pencegahan dan Pengendalian Penyakit, Maret 2020), hlm. 11.

10. Nagara, dkk. 2020. Buku Pedoman Pengorganisasian Kampung Tangguh: Langkah Sistemik Melawan Pandemi Covid-19. Universitas Brawijaya: Malang.

11. Nagara, dkk. 2020. Buku Pedoman Pengorganisasian Kampung Tangguh: Langkah Sistemik Melawan Pandemi Covid-19. Universitas Brawijaya: Malang.

12. Satgas Covid 19. 2020. Kampung Tangguh Melawan Covid-19: Kampung Tangguh Negara Kukuh. Artikel. Universitas Brawijaya: Malang.

13. Siagian. 2020. Mencari Kelompok Berisiko Tinggi Terinfeksi Virus Corona Dengan Discourse Network Analysis. Jurnal Kebijakan Kesehatan Indonesia : JKKI. 
https://jurnal.ugm.ac.id/ikki/article/view/55475/27989. [diakses 4 Desember 2020].

14. Syafrida \& Hartati. 2020. BersamaMelawan Virus Covid19 di Indonesia. Jurnal Sosial \& Budaya Syar-i. Fakultas Hukum: Universitas Tama Jagakarsa. 10.15408/sjsbs.v7i6.15325.

15. Tuwu, Darmin. 2020. Kebijakan Pemerintah Dalam Penanganan Pandemi Covid-19. Journal Publicuho. Universitas Halu Oleo: Kendari.Undang-Undang RI Nomor 36 Tentang Kesehatan.

16. Widoyono.2008. Penyakit Tripis Epidemiologi, Penularan Pencegahan dan Pemberantasannya. Jakarta: Erlangga.

17. World Health Organization. 2020. Penyebaran Penyakit COVID-19. Diakses di https://www.cnbcindonesia.com/tech/20200406090929-37149929/simak- penjelasan-who-soal-apa-itu-corona-dan-cirinya. 01 November 2020.

18. World Meters. 2020. Info Corona Virus. https://www.worldometers.info/coronavirus/. [diakses pada tanggal 25 Oktober 2020]

19. World Health Organization. 2020. Naming the coronavirus disease (COVID-19) and the virus that causes it. Geneva: https://www.who.int/emergencies/diseases/novel-coronavirus2019/technical-guidance/naming-the-coronavirusdisease-(covid2019)-and-the-virus-that-causes-it. [diakses 29 Oktober 2020]

20. World Health Organization. 2020. Penyebaran Penyakit COVID-19. Diakses di https://www.cnbcindonesia.com/tech/2020040609092937-149929/simak-penjelasan-who-soal-apa-itu-corona-dan-cirinya. 01 November 2020 19. [diakses pada tanggal 25 Oktober 2020]

21. Zahrotunnimah. 2020. Langkah Taktis Pemerintah Daerah Dalam Pencegahan Penyebaran Virus Corona Covid-19 di Indonesia. Jurnal Sosial \& Budaya Syar-i. UIN Syarif Hidayatullah Jakarta: Jakarta. 